\title{
Enhancing Capacity of Financial and Management Unit (UPKu) in Coastal Community Empowerment Program (P2MPP)
}

\author{
Niken Lastiti Veri Anggaini ${ }^{\text {a }}$ \\ ${ }^{a}$ University of Brawijaya, Malang, East Java, Indonesia
}

\section{INFORMASI ARTIKEL}

\section{Article history:}

Submission date: 10 October 2016

First revision: 25 October 2016

Accepted: 09 November 2016

Available online: 28 November 2016

Keywords: community empowerment, local institution, capacity building

\begin{abstract}
Generally, Financial and Business Management Unit (UPKu) is an unit based on local economic empowerment management that partner with village government. The research aims to describe and analyze the capacity building strategy of Financial and Management Unit (UPKu). The study applied interactive model of data analysis from Seidel. The result of the study showed that the strategy to gain capacity of UPKu conducted through three ways, namely human resource development, rural potential development and infrastructure development. Result of research showed that inadequate of fund and capacity of human resources that still low are the problems faced in implementation the strategy.
\end{abstract}

\section{INTISARI}

Unit Pengelola Keuangan (UPKu) adalah institusi lokal yang dibentuk berdasarkan manajemen pemberdayaan ekonomi lokal yang bermitra dengan pemerintah desa. Tulisan ini bertujuan untuk mendeskripsikan dan menganalisis strategi peningkatan kapasitas Unit Pengelola Keuangan (UPKu). Penelitian ini menerapkan model analisis data dari Seidel. Hasil penelitian menunjukkan bahwa strategi untuk meningkatkan kapasitas UPKu dilakukan melalui tiga cara, yaitu pengembangan sumber daya manusia, pengembangan potensi pedesaan dan pembangunan infrastruktur. Hasil penelitian menunjukkan bahwa keterbatasan dana dan kapasitas SDM yang masih rendah adalah masalah yang dihadapi dalam implementasi strategi.

2016 FIA UB. All rights reserved.

\section{Introduction}

As an unique life, coastal communities directly confronted the harsh conditions of ecosystems, and other resources that depend on the utilization of coastal and marine resources. Most of coastal community, especially fishermen was still entangled by issues of poverty and underdevelopment. There are certain issues related to coastal communities, i.e. aspects of ecological, social, and economic development. The low standard of living of coastal communities and limited access to assets and sources of financing for small fishing are the main problems encountered in coastal areas.

Based on World Bank data (Ola, 2012) about poverty, 108.78 million persons or 49 percent of Indonesia's total population live in conditions of poor and vulnerable to becoming poor. Figures were obtained based on less than two dollars per day. Most of poor people (63,47 percent) in Indonesia living in coastal and rural areas. Meanwhile, the Central Statistics Agency

* Corresponding author. Tel.: +62-823-3571-2799; e-mail: nik_fia@ yahoo.co.id 
(BPS, 2010) with different calculations from the World Bank, announced the poverty rate as of end March 2010, the number of poor in Indonesia was 31.02 million people. The amount is down 1.51 million when compared with figures in March 2009 amounted to 32.53 million. Currently, there are 11,25 percent of Indonesian population living below the poverty line (www. Jawapos.co.id, 11 Augustus 2010). In East Java, there are 38 regions and 22 are coastal region. The data from the 2008 East Java BPS states, there were 3.079.822 poor households (RTM) and 9.049.461 poor people.

As one effort to contribute to the prevention and alleviation of poverty in East Java, the Board of Community Empowerment (BAPEMAS) East Java province hold coastal community empowerment program. The program intended as an effort to develop the potential of the coastal region based on culture and local wisdom. In addition, through the empowerment of coastal community and coastal management are expected to achieve poverty reduction programs provisional and sustainable so that it can develop new patterns for innovative poverty reduction.

Financial Management and Business Unit (UPKu) is an unit that manages an existing business activities in the Village as the location of Program target. UPKu is autonomy local institution to develop social and economic activities of coastal community in Coastal Community Empowerment Program. The institution or unit has important role in developing productive activities based on village potential. UPKu managed autonomously by the community and the Government of Village which has a social nature of benefit to improving living standards and welfare of the coastal community. UPKu is an institution that capable of fostering economic incubation efforts for the community in coastal area. Institutions based community are expected to work closely with local, state and national government to ensure effective control of coastal community conflict so that they do not go beyond local levels. There are three business opportunities that can be applied by UPKu namely Savings and Loan sector, selfmanaged business sector, agribusiness (fisheries, livestock, agriculture and home industry) and business partnership. Some duties and responsibilities that related to financial management unit are clarification of Poor Households (RTM), business feasibility, serving the business capital loan applications, and report the implementation process, results of operations, and the actual use of funds and business development to the Government.

Studies on the role of local institutions in development have become an important issue as the emergence of a development paradigm based on community empowerment. Before local institutions or social institutions was established by the government as a consequence of development programs such as LKMD, Farmers Group, the society has set of institutions that emerge and arise from the initiative of local communities to meet needs his life. Generally, these local institutions have the character of cultural, religious and traditional with a variety of shortcomings in terms of organization/ modern institution (Suyanto, 1995:23-24). Further, according to Suyanto, on the other hand the government as a stakeholder of the development programs, it also requires local institutions that are reliable as a container and means of development in order to accelerate rural development. Based on the reality the government issued a policy regarding the need for a modern social institutions designed specifically to carry out certain development programs. Meanwhile, according to Peter in Bengen (2001:141-142), so far the efforts of NGOs to be a bridge or driving stakeholder participation in the formal policy-making seems to have not shown the results widely. Governance of natural resources (especially coastal and marine resources) is still undergoing the process of maturation. Formal planning cannot be effectively achieved by formal planning activities that take root and develop in society. Work at the grassroots level has not been successfully attached and made a part of the formal system. Working results of participatory community mapping, for example, yet many who later became an input to spatial planning and the underlying policy and decision making.

Research that tries to reveal the local institutions is also expressed by Suharno (2005), entitled Potential local institutions for community-based water resource management. This study tried to see the potential of local institutions for management that can ensure the preservation of natural resources as well as a carrying capacity of a society that inhabit. Research results revealed that the institution became an important element for the success of efforts to balance between humans and the environment. Institutional conditions ideal for the CBM (Community based management) if the local community has the form of institutional leadership level, the degree of observance, the rule of law, so that the institution has resilience and high durability

By knowing some conditions mentioned above, the research try to describe and analysis the strategy to enhance capacity of Financial and Management Unit (UPKu) in Coastal Community Empowerment Program (P2MPP). So the research problem is What are the strategy to enhance capacity of Financial and Management Unit (UPKu) in Coastal Community Empowerment Program?. 


\section{Theory}

\subsection{Community Empowerment}

According to Schuftan (1996), Community empowerment can be worked in a four-pronged approach that consists of:

a) Service (service delivery), the characteristic is a community development approach which refers to actions that relate directly to the main cause of failure of development;

b) Build capacity (capacity building), the characteristic is a community development approach to increase public knowledge, awareness and skills for using their own capacities and on the support system available to tackle the underlying causes of development failure;

c) Advocacy, the characteristic is a community development that establishes a dynamic process in building consensus and mandate for action; and

d) The social mobilization, the characteristic is community-development approach to put people who are actively involved in the assessment-analysisaction of the development process which refers to the more fundamental causes of the failure of development in an effort to improve their own empowerment.

Empowerment in the practice of social changes according to Hikmat (2004) has three main strategies, namely:

a) Traditional Strategy: advised to know and choose the best interests freely in various activities;

b) The direct-action strategy: the dominance of interests need to be respected by all parties involved, in light of the changes taking place; and

c) Transformative strategy, suggesting that public education in the long run is needed before the identification of self-interest.

Empowerment is the ability of individuals to gain control socially, politically, economically, and psychologically through (1) access to information, knowledge, and skills; (2) decision making; and (3) individual self-efficacy, community participation and perceived control (Rappaport, 1986:23). It can be concluded that empowerment is change process to gain the power and capacity of people (individual or groups) so they can make choice by themselves.

\subsection{Capacity Building}

Capacity building is a set of strategies aimed at improving the efficiency, effectiveness and responsiveness in the framework of the government's performance, with a focus on the dimension of human resource development, organizational strengthening and institutional reforms (Grindle, 1997). In the context of human resource development, attention is given to the procurement or provision of professional and technical personnel. The activities undertaken include training, salary/ wages, working conditions and environment settings and proper recruitment system.. In connection with the strengthening of the organization, attention is paid to the management system to improve the performance of the Functions and duties that exist and micro system settings. While institutional reforms, need to be given attention to changes in the system and the institutions that exist and influence the macro-structure. In this context the activities that need to be done is to change the main rules main, the policy change and the rule of law and institutional reforms that can drive the market and the development of civil society (Grindle, 1997).

\subsection{Local Institution}

Local institution is formed into two mechanisms, formal and informal that shape social and individual expectations, interactions, and behavior. It can be divided into public sectors, civic sectors and private sectors. Public sector consists of local government and bureaucratic administrative unit. Civic sector consists of membership and cooperative organization. And the last sector consists of service and business organization (Uphoff, 1986:47). Institutions affect the rural community adaptation and their livelihood through three way. The first influence is related to climate risk impact. The second focus on the incentives structure and the last is associated with the intermediate role where local institution try to translate and transfer the outside intervention to local context (Uphoff, 1986:47).

According to Esman dan Uphoff, Local institution range from public sector to private sector channels of activity, with and intermediate sector of membership organizations that have both public and private characteristics, (Uphoff, 1986:4). The major categories of local institutions can be classified as follows:

a) Local administration (LA):

Local agencies and staff of central government ministries, accountable to bureaucratic superiors

b) Local government (LG):

Elected or appointed bodies such as village council, having authority to deal with development and regulatory tasks and accountable to local residents, in contrast to LA

c) Membership organizations (MOs):

Local self-help associations whose members may seek to handle:

- Multiple tasks, e.g. local development associations or village development committees;

- Specific tasks, e.g. water users'associations managing irrigation or health committees overseeing village programs; or 
- Needs of members who have some particular characteristic or interest in common, e.g. mother's club, caste associations or tenant unions.

d) Cooperatives: Kinds of local organization that pool members' economic resources for their benefit, e.g. marketing associations, credit union, and consumer societies

e) Service organizations (SOs): Local organization formed primarily to help persons other than members though members may benefit from them. Examples are religious or charitable associations, service club.

f) Private business (PBs): either independent operations or branches of extra-local enterprises engaged in manufacturing, service and/ or trade (Uphoff, 1986:4-5).

Briefly, the functions of local institutions are:

a) Communication tool between government and communities and also between the members of the community itself (two-way communication);

b) Being a carrier's participation in order to support government development programs;

c) A means of improving community skill;

d) A means of modernization in order to change patterns of society that traditional static become dynamic and rational; and

e) A means of improving welfare of society (Mubyarto 1988:25).

\section{Research Method}

The kind of the research is qualitative research by descriptive approach. It conducted some methods in collecting data, such as interview, observation and documentation.

The focus of the research is the strategy to enhance capacity of UPKu, namely human resource development, infrastructure development and rural potential development. In order to analyze the data, it applied qualitative data analysis by Seiddel (1998:2-5)). It consist of three parts, that is noticing things, collecting and sorting instances of things, and thinking about things. Noticing means making observations, writing field notes, record interviews, gathering documents and so forth. In the noticing things step, the researcher also conduct data coding. Collecting means grouping data based on each code that has been done before into certain characteristics to be arranged into a complete picture. Sorting instances of things is the process of filtering the data, looking for the type, class, order, process, design or integrity. While thinking about things is data checking and data meaning. The purpose of the last process is to make some kind of sense out of any collection of data, looking for patterns and relationships in data collection, to make research findings and finally draw a conclusion.

\section{Result and Discussion}

\subsection{Result of Research}

\subsubsection{Human Resources Development}

Generally, quality of human resources in organizations, both public and private organization is very important for developing organization in the future. The improvement of human resource capacity in this research are conducted through training, internships and visiting study. In the research, It aims to invest resource development for supporting quality of service and productivity management UPKu business, community groups (UEP) and other parties concerned.

The training is intended to increase human resource capacity to be able to manage the business optimally. It could be in the form of financial administration training, entrepreneurship training, training development of quality production, computer training, business management and others.

Meanwhile Organizational structure of UPKu is divided into two groups, supervisors and administrators. It can be seen in figure below:

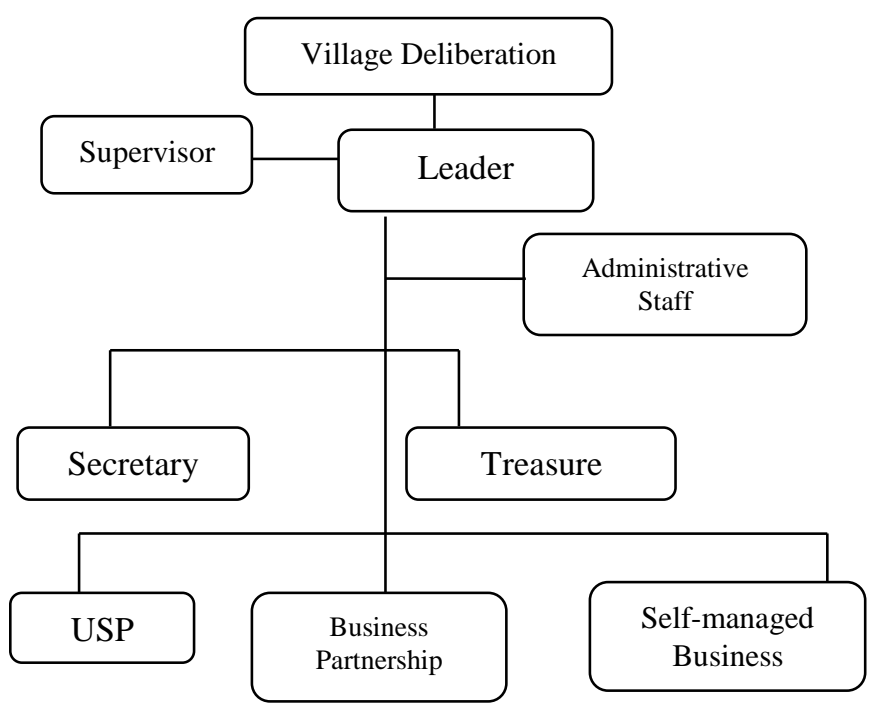

Figure 1 Board of UPKu

Source: Standard Operational Procedure (SOP)

Coastal Community Empowerment Program, 2010

UPKu Supervisor is the governing body whose function is to provide oversight and internal policies against UPKu operational. In performing the role and functions, the Supervisory quite relate and coordinate with the Chairman of UPKu. Supervisor consists of head of Village and 2 people from Community leader are chose.

Meanwhile, the level of education of administrators UPKu can be seen in the following table: 
Table 1 List of Education Level of UPKu Administrator

\begin{tabular}{|c|l|c|l|}
\hline No & \multicolumn{1}{|c|}{ Name } & Position & \multicolumn{1}{|c|}{ Degree } \\
\hline 1 & RoghibulYadum & Chairman & Bachelor \\
\hline 2 & M. Burhan & Secretary & $\begin{array}{l}\text { Junior High } \\
\text { School }\end{array}$ \\
\hline 3 & Siti Rohmatin & Treasures & $\begin{array}{l}\text { Senior high } \\
\text { school }\end{array}$ \\
\hline
\end{tabular}

Source: Primary Data Collected in Field Research, 2012

The table showed that the level of education administrators UPKu "Maju Bersama" is relatively good in conducting their activity, even the chairman UPKu is bachelor degree. Furthermore, This also showed that education is also one of the factor considered to be the organization committee. In order to optimize the role of $\mathrm{UPKu}$ as a capable unit on fostering economic incubation efforts for coastal community, and serves to develop productive activities in accordance with the potential, such as savings and loans, sectors of fisheries, animal husbandry, agriculture, home industrial and coastal tourism, the development of human resource absolutely to be implemented. It can be seen as the following table:

Table 2 List of Human Resources Training

\begin{tabular}{|c|l|l|}
\hline No. & \multicolumn{1}{|c|}{ Name of Training } & \multicolumn{1}{|c|}{ Participant } \\
\hline 1 & Financial Adimistration & Board of Upku \\
\hline 2 & Organization Management & $\begin{array}{l}\text { Board of UPKu } \\
\text { and UEP }\end{array}$ \\
\hline 3 & $\begin{array}{l}\text { Production Management } \\
\text { and Marketing Training }\end{array}$ & UEP \\
\hline
\end{tabular}

Source: Primary Data Collected in Field Research, 2011

This effort is intended to increase institutional capacity of the human resource sector. Related to this, it has been carried out some training, such as the Financial Administration and management of the organization/ institution. The training was given to UPKU administrator (Board of UPKu). Besides that, development of institutional quality of UPKu also addressed to the members of community group (UEP). It showed that the need to enhance capacity not only becomes a need of board of UPKu but also community. It have to run together in order to accelerate process of empowerment. Beside Production Management and Marketing Training, in order to develop human resources quality, it was conducted comparative study. Comparative study was carried out by visiting other $\mathrm{UPKu}$, community groups or other institutions which have management and institutional performance relative better. The result of research showed that several actor are involved in the comparative study such as village government, board of UPKu, and economic productive unit (UEP) itself.

\subsubsection{Rural Potential Development}

The second effort to improve the institutional capacity of UPKu implemented through empowerment potential ofthe village. It was held by providing working capital loans to community groups for productive economic activity. The following table is list of community groups who gain from the venture capital loans of UPKu Maju Bersama.

Table 3. List of Recipients of Business Savings and Loans

\begin{tabular}{|c|l|c|c|}
\hline No. & \multicolumn{1}{|c|}{ Description } & $\begin{array}{c}\text { Number of } \\
\text { member }\end{array}$ & $\begin{array}{c}\text { Total Cost } \\
(\mathbf{R p},-)\end{array}$ \\
\hline 1 & UEP "Shrimp” & 16 Member & $23.000 .000,-$ \\
\hline 2 & UEP “Anchovies" & 11 Member & $17.500 .000,-$ \\
\hline \multicolumn{3}{|c}{} & $40.500 .000,-$ \\
\hline
\end{tabular}

Source: Accountability Report of UPKu Maju Bersama, 2011

Based on the above table, the venture capital lending has not reached all productive economic unit that develops in the Gadon village, such as business crackers, dried fish and shrimp paste because of limited of funding. Basically, UPKu was prepared to be able to partner with other institutions and fund managers of CSR. There are three business opportunities that can be done by UPKu i.e.:

a) Savings and Loan Unit (USP);

b) Enterprises can be either self-managed agribusiness sector (fisheries, livestock, agriculture and home industries) and Tourism Sector; and

c) Business Partnership.

Based on the research result, beneficiary savings and loans consisted of 12 poor households (RTM) and 14 near-poor households (RTHM). Loans have been fairly evenly, reaching $2 \mathrm{RW}$ located in Gadon. These loans are prioritized on the poor and near poor who have a business that could be developed.There are several steps taken in analyzing the loan, which is as follows:

a) Research completeness of administrative documents, the truth of charging, the amount of the loan application with the ability of potential borrowers, as well as the completeness of documentation;

b) Assessment of borrower character. This assessment aims to assess the prospective borrower's ability to pay. This assessment is done by checking and extracting information from various sources, mainly related to whether the prospective borrower can be believed to be "going back" the loan or not. Aspects analyzed includes character and commitment of the prospective borrower. People who have good character, in general, will meet all its obligations, that is to return the loan. Therefore, UPKu administrators trying to not make loans based solely on the consideration of (i) compassion, (ii) because the contacts (siblings or friends), and (iii) the 
prospective borrower is an honorable man (wellknown, respected, social status height); and

c) An assessment of the prospective borrower's ability to pay calculation of ability to pay back the loan is to analyze the ability of members/ community groups to UPKu by looking at the feasibility of the business and household incomes (husband, wife, child or other family members are able to generate income) and reduced by the costs that need issued in the household, so that the net revenue picture will be obtained.

Actually, program funding was derived entirely from the government. With the limited funds, It does not only have an impact on uncover the entire UEP in Gadon but also to sustainability program. The condition made developing the potential of the village cannot be optimally implemented. It may be different condition if UPKU builds partnership to other social and economics unit in order to support the program. In this term, the function is not only related to get supporting funding but also other resources likes infrastructure, links, human resources, knowledge and skill.

\subsubsection{Development of Infrastructure}

Another effort that is not less important to improve the quality of institutional UPKu can be conducted through the development of infrastructure, such as the secretariat room, the administrative and financial books, computer, board of service schedule, organizational structure board, scheme of service mechanisms, and board of UPKu activities, etc. The following table is the availability of UPKu infrastructure in conducting role as intermediate economic unit for empowerment program of coastal community.

Table 4 Result of Monitoring of Several Infrastructure of UPku

\begin{tabular}{|c|l|c|}
\hline No & \multicolumn{1}{|c|}{ Indicators } & Status \\
\hline 1 & Data of poverty & Available \\
\hline 2 & BOP and activity report & Available \\
\hline 3 & Loan report & Available \\
\hline 4 & Documentation & Available \\
\hline 5 & $\begin{array}{l}\text { Data of environment } \\
\text { infrastructure condition }\end{array}$ & Available \\
\hline 6 & Data of educational facilities & Available \\
\hline 7 & $\begin{array}{l}\text { Data of social infrastructure } \\
\text { condition }\end{array}$ & Available \\
\hline 8 & Data of economic condition & Available \\
\hline 9 & Schemes of service mechanisms & $\begin{array}{c}\text { Not } \\
\text { Available }\end{array}$ \\
\hline 10 & Board services schedule & $\begin{array}{c}\text { Not } \\
\text { Available }\end{array}$ \\
\hline 11 & $\begin{array}{l}\text { Information board of UPKu } \\
\text { activities }\end{array}$ & $\begin{array}{c}\text { Not } \\
\text { Available }\end{array}$ \\
\hline
\end{tabular}

Source: Bapemas, PD KB Tuban, 2011
In carrying out operational activities and provide business services, UPKu secretariat was located in the Gadon village hall. Besides that, another infrastructure that must be completed is administration and financial book. This book is used to record all transactions. So, UPKu Board must comply with criteria and principles in bookkeeping, ie fulfilling the elements of chronological (sequentially according to the date of the transaction), systematic (can be grouped according to the post, such as wealth group, capital group, debt group, income group, the group costs and so on), informative (can be read and understood in general from the standpoint of financial statements) and auditable (can be proven and justified because of the recording made based on the evidence of transactions). The books are to be prepared include: organizational administration book and financial administration book. These books consist of books of institutional administration and financial administration. Institutional administration book consist of: 1. Register of Members/ community groups Book 2. Minutes Book 3. Guest Book, etc. Meanwhile the book Financial Administration Book consists of: daily cash mutation book, daily cash recapitulation book, cash enters book, cash out book, memorial journal book, effort balance book, balance report and statistical data. In addition, UPKu must also complete with book register of borrow, savings card, loan card, savings book, deposit slip/ receipt withdrawal.

\subsection{Discussion}

\subsubsection{Human Resources Development}

In general, human resource is strategic factor in all program activity. Human Resource is a major factor as an element manager for Coastal Community Empowerment Program (P2MPP). The provision and empowerment of human resources is also directed to create forces capable of managing and running tasks and functions well, so the goal of program can be achieved at an optimal. Besides, it also have implications for the function of public management in the implementation of the processes of planning, organizing, staffing, directing and controlling human resources management. Human resource strategic role in managing the program can be elaborated in terms of public management theory, in which institutions function organizers are putting all the internal resources or the ability to run and manage the program. Result of research showed that training was established to enhance capacity of local institution consists of management organization, financial management, production management and marketing, comparative study. Comparative studies can be followed by administrator of UPKu (Board of UPKu) and UEP. Comparative study was carried out by visit in UPKu, community groups or other institutions which the management and institutional performance relative 
better. Meanwhile, training was conducted by wreaking instructor directly to the location or sending some of them out there. Besides instructor, the program also presence village companion team who assist coastal community in doing their activity until the program end. The presence of a companion is to be especially needed in any empowerment program because society cannot walk alone. It is probably because of lack of skill and knowledge, limited fund, lack of confidence etc. But most important of this assistance is to put the right person at the right place also. Furthermore, human resource development also was built in lines with the effort to prepare village cadre. This activity is significant for continuity of the program. Empowerment paradigm has assumption that development goes on by itself when the society are given the right to manage natural resource that they have and use it for the society development. But this would be difficult to achieve success in creating an independent society when not accompanied by advocacy efforts, especially for the backward state of society. Meanwhile, Ife (1995:182) provides a definition of empowerment as an effort providing the people of the source, opportunity, knowledge and skills to gain their capacity in determine their lives and their communities. And to support that there should be involved three actors, state, private and public sector.

Based on research data, the development of institutional quality of UPKu is not only aimed at the managers or board of UPKu but also for community group that involved in unit economic production (UEP). This is important for more tangible benefits of the program that also felt by the community. According to Grindle (1997: 6-22) capacity building is effort to develop a range of strategies to improve efficiency, effectiveness and responsiveness to the community that is efficient in terms of time and resources required to achieve an outcome, the effectiveness of merit of the work done for the sake of results cooled, and responsiveness in how to synchronize between our needs and abilities for that purpose. Furthermore, Grindle said that in capacity building should focus on three dimensions, namely human resource development, organizational strengthening and institutional reforms.

The dimensions of capacity building is also expressed by A. Fizbein (1997). He stated that the increased ability have to focus on 1) the ability of human resources or labor (labor), 2) the technology that embodied in the form of infrastructure support. 3) the capital that embodied in the form of support resources, facilities and infrastructure. Whereas according to Moenir (2006:117) with the ability and skills that are adequate then the execution of tasks / jobs interchangeable can do well, quickly and fulfill all the wishes of all parties, both the board itself and also the community. It can be concluded that the availability of competent human resources and efforts to increase the capabilities and skills through human resources development program is needed to support the improvement of service quality of UPKu associated with the task that is not only as an intermediary institutions and channeling of funds from government to society, but also how the money is safe, well developed and can be best utilized for the development of productive activities in society. Communities should also participate in their own empowerment. Goals, methods and results should be formulated by their own.

\subsubsection{Rural Potential Development}

The second effort to improve the institutional capacity of UPKu implemented through the empowerment potential of the village. Result of research showed that It conducted by providing working capital loans to community groups for productive economic activity. Empowerment of coastal communities through venture capital is also consistent with the theory of capacity building of Grindle (1997) who explains that one of capacity building through strengthening the organization can be achieved through venture capital loan

This is also consistent with community empowerment as expressed by Sulistyani (2004:79) that empowerment is an effort to build the power, by encouraging, motivating and raising awareness of its potential and seeks to develop it. Economic enterprises of poor coastal communities rather helpless at all, but they have something even a little, such as land, labor, family, hard-working spirit of mutual aid and so forth. With proper empowerment, economic enterprises of poor coastal communities have the opportunity to develop.

The description above is also not much different from the concept of empowerment expressed by Kartasasmita (1996:178-179) that the government in this case as a change agent can apply a policy of empowering the poor with a three-way destination that is enabling, empowering and protecting. In this research, enabling performed by open access to financial services by the form of deposits and borrower. Empowering and protecting activity were done by establishing UPKu as a means and space for coastal communities to develop their potential and also protect the poor. Program priority and supporting activity are based on the aspirations of rural communities through village meetings. This is in line with research J. Johannes Tulungen, Priciellia Kussoy and Brian R. Crawford, that the Coastal communities can play a larger role in coastal resources management than has been acknowledged previously in Indonesia. If communities are well trained and empowered, they can be transformed from coastal 
resource users into coastal resource managers, both from the perspectives of the communities and of local government

\subsubsection{Infrastructure Development}

In general, Financial and Business Management Unit (UPKu) is institution based economic empowerment that partner with village government, and is managed autonomously by the people, who scouted by Bapemas Province to tackle poverty. Another effort that is not less important to improve the quality of UPKu built through the development of infrastructure facilities, either through supporting infrastructure as well as secretariat room and completeness of administrative and financial book. Furthermore, to enhance quality of UPKu service, the several infrastructure must be completed are board of service schedule, scheme of service mechanisms, and board of UPKu activities. All of these infrastructure are important both for public/ community and board of UPKu itself in doing their tasks.

Institutional quality improvement efforts through infrastructure development is in line with the dimensions revealed by Fiszbein (1997), that the performance improvement are focused on 1) the ability of labor (labor), 2) the ability of the technology that embodied in the form of institutional organization and 3) the ability capital that embodied in the form of support resources, facilities and infrastructure. Moreover, Moenir (2006:119) was also stated that service facilities are all kinds of equipment, work equipment and other facilities that serve as the main tool in the implementation of the work, and social functioning within the framework of the interests of the people who are dealing with that agency. By adequate infrastructure, public will get clear understanding about what they will do, what requirements have to fulfill if they want to get service from UPKu related to its role in developing economic productive activities. It can be concluded that presence of main and secondary infrastructure in the right quantity, in the right place and in the right time are significant way to support role of financial and management unit (UPKu).

\section{Conclusion}

The strategy to gain institutional capacity of UPKu were conducted through three ways, namely human resource development, the development potential of rural and infrastructure development.

a) Development of human resources devoted to UPKu administrators (broad of UPKU) and community groups/ productive economic units (UEP). It were conducted through training and comparative study. Result of research showed that training was established to enhance capacity of human resources consist of management organization, financial management, production management and marketing of marine products. UPKu Maju Bersama have some problems in doing their task that causes by inadequate of fund and capacity of human resources that still low;

b) The rural potential development aims to develop a productive economic unit through study comparative, the provision of working capital loans and business training. The strategy also could not be conducted optimal because of limited of fund; and

c) Infrastructure development was conducted through the provision of facilities such as secretariat room, completeness of administrative and financial books. Furthermore, there are several things that also must be completed such as board of service schedule, scheme of service mechanisms, and board of UPKu activities in order to enhance service quality of UPKu.

Gradually, developing institutional capacity of UPKu have to be focused on efforts to gain capacity and quality of UPKu so can manage projects independently and become a local financial institution based on society. For example by building partnership with other financial institutions and fund managers of CSR, so governance principles embodied, that is a partnership among government, public and private sectors in an effort to empower the poor. Besides, Efforts to increase the community empowerment must be grown on public awareness, which be able to empower themselves and be balanced with the assistance of its steering than rowing. Improving the quality of human resources can be done by adding a companion who not only is based on educational background, but also preferably derived from the local area having better understand the situation and condition of society so that the process of empowerment can be implemented well.

\section{References}

Bengen, Dietriech, G. (2001). Prosiding Pelatihan Pengelolaan Wilayah Pesisir Terpadu. Pusat Kajian Sumber Daya Pesisir dan Lautan (PKSPL) IPB, Bogor.

Fiszbein, A. (1997). The Emergence of Local Capacity: Lesson from Columbia. World Development, Vol 25, No. 7, pp. 1029-1043.

Grindle, M.S. (editor). (1997). Getting Good Government: Capacity Building in The Public Sectors of Development Countries. MA: Harvard Institute for International Development, Boston.

Hikmat, H. (2001). Strategi Pemberdayaan Masyarakat. Bandung: Humaniora Utama Press.

Ife, Jim. (1995). Community Development: Creating Community Alternatives-Vision, Analysis and Practice. Australia, Longman Pty Ltd. 
Kartasasmita, Ginandjar. (1996). Pembangunan untuk Rakyat, Memadukan Pertumbuhan dan Pemerataan. Jakarta: Cides.

Moenir, AS. (2006). Manajemen Pelayanan Umum di Indonesia. Jakarta: Bumi Aksara.

Mubyarto. (1988). Gerakan Penanggulangan Kemiskinan. Aditya Media, Yogyakarta.

Rappaport, J. (1986). In Praise of Paradox. A Social Policy of Empowerment over Prevention. In E. Seidman \& J. Rappaport (Eds), Redefining Social Problems, pp.141-164. New York: Plenum Press.

Schuftan, Claudio. (1996). The Community Development Dilemma: When are service delivery, capacity building, advocacy and social mobilization really empowering?. Community Development Journal, Vol.31 (3), pp. 30-35.

Seiddel, John V. (1998). Appendix E: Quatitative Data Analysis. Available at http://www.qualiresearch.com/Downloads/qda.pd f/ [Accessed 20 February 2016].

Suharno. (2005). Potensi Kelembagaan Lokal Bagi Pengelolaan Sumberdaya Air Berbasis Masyarakat. Project Working Paper Series No.11 $\mathrm{Mei}$ 2005, Pusat Studi Pembangunan -Institut Pertanian Bogor Bekerjasa sama dengan Partnership for Governance Reform in Indonesia - UNDP.

Sulistiyani, A.T. (2004). Kemitraan dan Model-Model Pemberdayaan. Yogyakarta: Penerbit Gaya Media.

Badan Pemberdayaan Masyarakat Provinsi Jawa Timur. (2010). Standard Operational Procedure (SOP) Program Pemberdayaan Masyarakat Pesisir dan Pantai Tahun 2010.

Suyanto, B. (1995). Perangkap Kemiskinan: Problem dan Strategi Pengentasannya. Surabaya. Airlangga University Press

Uphoff, Norman. (1986). Local Institutional Development: An Analytical Sourcebook with Cases Amerika. Kumarian Press

BPS (2013). Jumlah dan Persentase Penduduk Miskin, Garis Kemiskinan, Indeks Kedalaman Kemiskinan (P1), dan indeks Keparahan Kemiskinan (P2)menurut Provinsi, 2007-2009 (Maret), 2010-2011, 2012 (Maret dan September) Available https://www.bps.go.id/linkTabelStatis/view/id/14 89/ [Accessed 14 March 2016].

Ola (2012). Penghitungan Angka Kemiskinan BPS vs Bank Dunia. Available at https://www.statisticscafe.blogspot.co.id/2012/02/ penghitungan-angka-kemiskinan-bps-vs.html/ [Accessed 10 September 2016]. 